\title{
Mariola SOBOLEWSKA
}

Katolicki Uniwersytet Lubelski

\section{THE ORPHIC THEOGONIC POEMS ATTRIBUTED TO LINOS. NOTES ON THE TESTIMONY OF PAUSANIAS}

\author{
LOS POEMAS ÓRFICOS TEOGÓNICOS ATRIBUYEN A LINOS. \\ NOTAS SOBRE EL TESTIMONIO DE PAUSANIAS
}

\begin{abstract}
Pausanias conoció poesía atribuida a Lino y la consideró espuria, al igual que la mayoría de los trabajos de Orfeo y Museo. En su opinión, Lino no había compuesto un solo verso y, si lo había hecho, no se había conservado. Lo único que menciona acerca del contenido de la poesía atribuida a Lino es que ofrece un relato sobre Éstige similar al que aparece en Hesíodo, quien la considera hija de Océano y esposa de Palas. Otros autores antiguos escriben sobre las otras obras atribuidas Lino. Ninguno de ellos no explica por qué tantas obras atribuidas Lino. Mi artículo es la respuesta a esta pregunta.
\end{abstract}

Palabras clave: Lino, Pausanias Periegetes, las creencias órficas, la teogonía órfica, los órficos

In this article I am going to discuss Linos' connection to the Orphics that can be noticed in Pausanias' Description of Greece (West, 1983; Martínez, 2008). That person has not yet received his deserved place among the masters of Orphics, despite that it appears that he had similar influence on them as Musaeus did. Linos first appears as someone lamented in a ritual song, or as the name of the song (Hom. Il. 18.570). From quite an early date he was represented as a singer himself. In one Hesiodic fragment he is the son of the Muse Urania (we remember that Orpheus was also the son of a Muse), and in another that may well connect with it he is ,learned in every sort of poetic skill" (Hes. Theog. 305-6). Heraclides Ponticus had him composing laments, because he was the subject of laments. Eventually the step was taken of composing poems in his name. This may have begun before the end of the third century BC, since he was listed as a sage, together with Orpheus, in Hippobotus' Register of Philosophers, which is dated to that period (Diog. Laert. 1.42).

We will take a closer look on how did Pausanias refer to him. He writes that Linos supposedly described in his poems the genealogy of the first gods of Greek 
pantheon, similar to Hesiod's Theogony. Passage in question of Periegesis, we read:

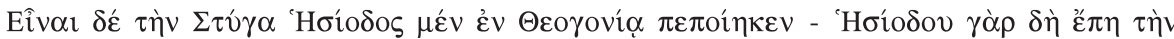

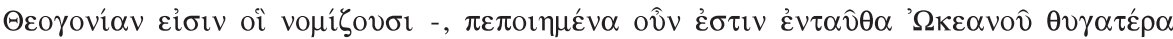

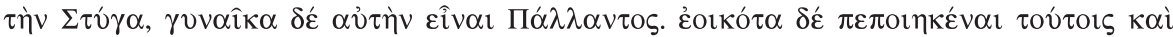

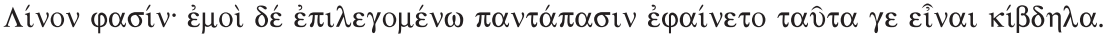

Hesiod in the Theogony for there are some who assign this hexameter poem to Hesiod speaks of Styx as the daughter of Ocean and the wife of Pallas. Men say that Linos too gives a like account in his verses, though when I read these they struck me as altogether spurious (Paus. 8.18.1; Rocha-Pereira, 1973-1981; Jones, 1966-1971).

Pausanias may be referring to following passages of Hesiod's Theogony, where those deities are mentioned. In one of those fragments, Hesiod writes:

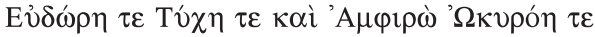

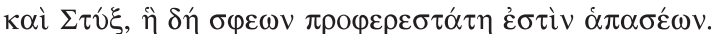

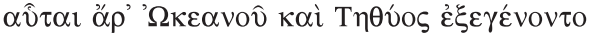

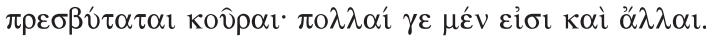

Eudora, and Tyche, Amphirho, and Ocyrrhoe, and Styx who is the chiefest of them all.

These are the eldest daughters that sprang from Ocean and Tethys; but there are many besides (Hes. Theog. 360-363; West, 1966; Most, 2006).

It is more probable that he has in mind the following passage of Theogony, where we can read:

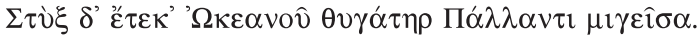

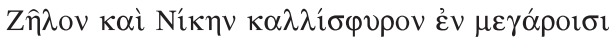

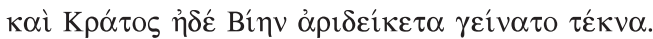

And Styx the daughter of Ocean was joined to Pallas and bore Zelus and trim-ankled Nike in the house.

Also she brought forth Cratos and Bia, wonderful children (Hes. Theog. 383-385; West, 1966; Most, 2006).

According to Martin L. West the one thing he mentions about the content of the poetry ascribed to Linus is that it gave a similar account of Styx to that in Hesiod, who made her the daughter of Oceanus and wife of Pallas. It is not easy to imagine that divine genealogies of the conventional Hesiodic kind were incorporated in the cosmological poem that other authors cite (West, 1983: 61). Obviously, it is possible that the Linos' poem differed from Hesiod's Theogony in other aspects and showed similarities only in presenting the family relationships of Styx. 
It remains to mention that Pausanias knew poetry attributed to Linus, and judged it to be spurious. Pausanias doubted even that Hesiod is really the author of Theogony, which can be seen in the discussed fragment from Periegesis, however scientific research proved otherwise, conclusively and long time ago. Pausanias seemingly used to question the fact that a text signed with a name of an author really had been written by him. Thus, one should be even more careful when he indicates uncertain authorship of Orphic texts of Linos, because such claims may be unsubstantiated.

On the basis of this information, one can assume that in times of Pausanias, some poems ascribed to Linos must have existed - poems that resembled Hesiod's Theogony. This work, in turn, has provided a model for the form and content for the later Orphic theogonies (Von Albrecht, 1997: 270). They took from it the generations of gods, their names and family relationships, ascribing the authorship to Linos. It is also possible that the Linos' poem might have included an Orphic theogony, but one cannot be absolutely certain on the basis of the information in Pausanias' work.

To find connections in the subject matter between the fragment mentioned in Periegesis and the texts we consider Orphic, one should examine the role of the deities mentioned there. Lech Trzcionkowski noted that classical authors referring to theogonic poems mention in the first generation of gods Oceanus and Tethys (2013: 37). In the Linos' work we can observe something similar. One should think about the relationships and appearances of Styx as a daughter of Oceanus and Tethys and a wife of Pallas in other Orphic texts. Although none of the texts confirms that the goddess was indeed a wife of Pallas, but there exist many Orphic texts mentioning Styx and Oceanus as being gods and sometimes tying them with kinship. Both deities are present in the preface to the Orphic hymns (Ricciardelli, 2000; Morand, 2001; Ricciardelli, 2008; Rudhardt, 2008), where it is invoked that: „The great Okeanos together with his daughters (' $\Omega \kappa \varepsilon \alpha v o ́ v$

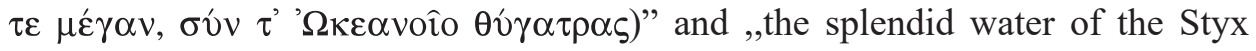
( Fayant, 2014; Athanassakis, 2013). It is also possible that, in this context, one of Oceanus' daughters was Styx. Moreover, one should not neglect the fact that the Orphic hymn no. 83 is addressed to Oceanus.

Oceanus and Tethys are mentioned also in two among all the known Orphic theogonies. The first of the theogonies was discussed in the Derveni Papyrus (Laks, 1997; Betegh, 2004; Kouremenos, 2006), where, in column 23, according to the system proposed by Richard Janko, we read:

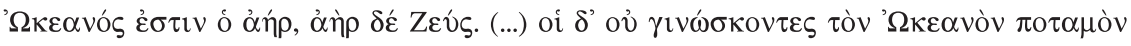

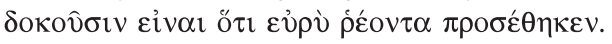

Ocean is Air, and that Air is Zeus. (...) But those who do not comprehend it suppose that Ocean is the river, because added the epithet wide-flowing (PDerv. col. 23, 3-7; Janko, 2002). 
The other theogony that mentions Oceanus and his wife is that which has been commented on by Eudemus of Rhodes, to whom Damascius ascribes the following words:

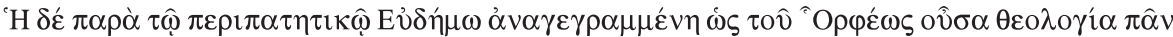

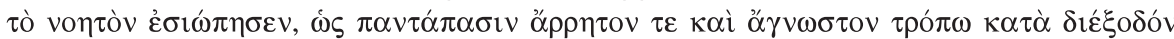

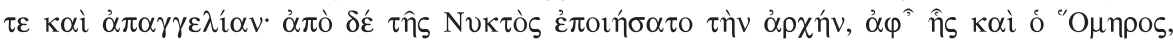

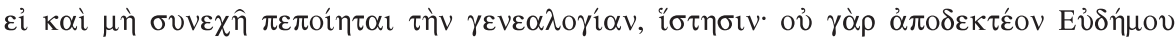

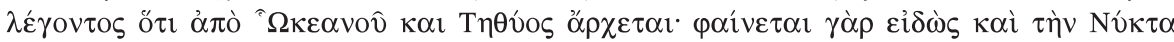

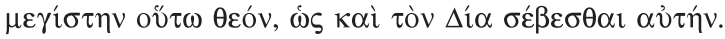

The theology that is recorded with the Peripatetic Eudemus as being by Orpheus is silent about the entire intelligible world, since it is completely ineffable and unknowable by means of discursive [thinking] or through [sacred] narrative. Eudemus begins with the principle of Night, from which Homer too begins, even if [Homer] (Hom. Od. 3.163) has not written a continuous genealogy. One must not agree when Eudemus says that Homer makes [everything] begin from Oceanus and from Tethus. Eor Homer clearly knew that Night was the greatest god, since Zeus himself feels reverence for her (Dam. Princ. 1.319.8-13; Ruelle, 1964; Ahbel-Rappe, 2010).

Oceanus alone appears also in the theogony summarized in the Birds of Aristophanes (Bernabé, 1995; Jiménez, 2004; Christopoulos, 2010), who says:

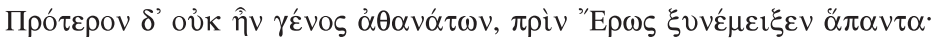

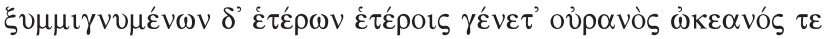

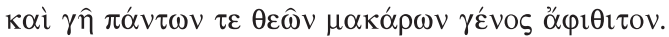

That of the Immortals did not exist until Eros had brought together all the ingredients of the world, and from their marriage Heaven, Ocean, Earth and the imperishable race of blessed gods sprang into being. Thus our origin is very much older than that of the dwellers in Olympus (Aristoph. Av. 690-702; O’Neill, 1938; Dunbar, 1995).

Moreover, it is worth noting that in this fragment the first entity is Chaos, which certainly existed before Oceanus. Chaos as the first entity appears in the work of Pseudo-Apuleius, where the author speaks in this context of theogony, inter alia by Linos. In De ortographia, we read:

Quamquam Orpheus Linus et Hesiodus deos ex Chao ab initio erupuisse dixerint.

Besides, Orpheus, Linos and Hesiod say that at the beginning the gods emerged from Chaos (Ps.-Apul. Orth. 44; Bernabé, 2007).

All the more, the similarity is striking for two reasons. Firstly because Linos' works were juxtaposed by the author with Hesiod's theogony, similar to what we find at Pausanias in a fragment of interest. Secondly, Pseudo-Apuleius speaks about a theogony where Chaos appears as the first entity, from which all other entities were made. Thus one can assume that the fragment of theogony about 
Styx, Oceanus and Pallas that Pausanias describes is its continuation. We can also assume that because this poem was similar to Orpheus' theogony, it is possible that it had contained Orphic content. We can reconstruct Linos' theogony in the following way. The first principle was Chaos, from which, inter alia, emerged Oceanus, and possibly Tethys, and who both conceived Styx. That goddess later married Pallas.

Returning for a moment to a theogony mentioned above, parodied in the Birds, according to Diogenes Laertius, Linos also spoke in similar tone as Aristophanes' account on how the world has come to existence (it appeared as a whole in one moment). Diogenes writes in The Lives and Opinions of Eminent Philosophers that Linos' work began with the following words:

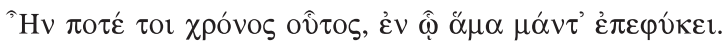

Time was when all things grew up at once (Diog. Laert. 1.4; Long, 1966; Hicks, 1972).

This mention should support that theogony in Linos' poem was close in the theme to the Orphic one known from Aristophanes.

We also know other texts that mention Oceanus and Styx in the context of Orphic beliefs and, above all, what Orpheus says. Oceanus indeed appears as a deity quoted by the Thracian singer in the light of Plato's Cratylus (Bernabé, 1998; Casadesùs, 2008; Bernabé, 2011), where Socrates supposedly said:

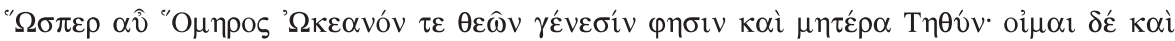

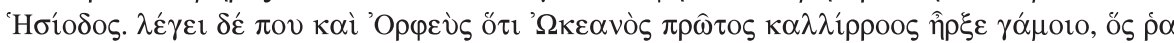

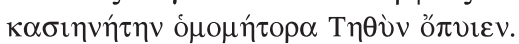

Just so Homer (Hom. Il. 14.201; 14.302), too, says: „Ocean the origin of the gods”, and ,their mother Tethys" and I believe Hesiod says that also. Orpheus, too, says fair-flowing Ocean was the first to marry (Plat. Crat. 402 b; Burnet, 1967; Fowler, 1970).

In this fragment we find the information about theogony professed by Orpheus, or at least ascribed to him by Plato. Doubtless, this philosopher, as we said before, read Orphic scriptures. Opheus' beliefs in the light of Plato's dialogue about the marriage of Tethys and Oceanus were identical to the beliefs of Homer and Hesiod on the same matter. It is possible that his beliefs about distant relatives of these deities were similar. By this I mean the family of Styx and, above all, her marriage with Pallas. Similarities between the genealogy of Oceanus and Tethys at Orpheus and of Homer and Hesiod are stressed also by Plato. We can notice that also on the basis of the fact that the presence of this pair of gods in Orphics' beliefs was common.

Another fragment, possibly from the same theogony, was ascribed to Linos by Diogenes Laertius, in the prologue to his work. He wrote: 


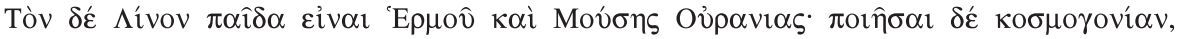

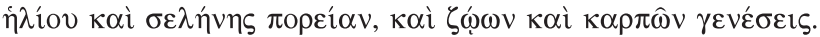

Linos again was (so it is said) the son of Hermes and the Muse Urania. He composed a poem describing the creation of the world, the courses of the sun and moon, and the growth of animals and plants (Diog. Laert. 1.4; Long, 1966; Hicks, 1972).

Before we can proceed to a more detailed analysis of the matter of this mention, let us ask a question if Laertius is writing here about one work of Linos', or several of them. We do not know, as Alberto Bernabé has pointed out, if the works enumerated by Diogenes Laertius are different fragments of a one work or different works (Martínez, 2008: 562). However, the manner in which they are written down by Laertius indicates rather that they are fragments of one piece, which could be a poem, partially consisting of the Orphic theogony, which, what we have already proven, resembled the theogony from the Aristophanes' comedy.

Let us now focus on the mention in The Lives and Opinions of Eminent Philosophers; Diogenes Laertius stated that Linos had written a poem about the beginnings of the world, the circulation of the sun and the moon and their birth. On the basis of it we can be under impression that the mentioned poem about the beginnings of the world can be in fact a theogonic poem. Since at the beginning of the world appeared deities. Therefore, perhaps the Linos' theogony discussed in that chapter was a part of the poem Diogenes Laertius describes.

On the basis of what the historian of philosophy published, we can conclude about the reach of Linos' works in the times when he was writing his The Lives of philosophers. He had to know, at least second-hand, the subject of works ascribed to Linos, or even to have read whole works, despite the fact that, most probably, he lived later than Pausanias. This information indicates that works of this poet circulated also in times of the author of Periegesis. It is probable that this poem included the theory of unity in multiplicity, popular among Orphics, at least according to contemporary scholars (Świercz, 2008). Perhaps the mentions of the genealogy of gods found in the sources aforementioned could be a part of this poem.

Returning, however, to the sentence written by Diogenes Laertius about a cosmogonic poem ascribed to Linos. West rightly notes that the initial verse of Linos' cosmogony, mentioned by Diogenes Laertius, resembles the beginning of the Orpheus' song in The Argonautica of Apollonius of Rhodes, which may indicate that Linos was the author of texts similar to the songs of Oeagrus' son (1983: 58), unless what the Rhodian has done was a result of a coincidence, which cannot be ruled out. Orpheus was a songster and performing songs was one of his activities. We are going to take a closer look at this fragment of The Argonautica of Apollonius of Rhodes and compare it to what we know about the beginnings of the world according to Linos, on the basis of the sources already discussed, to show possible similarities and differences between them. At the Rhodian we read: 


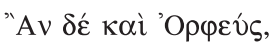

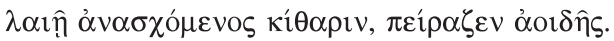

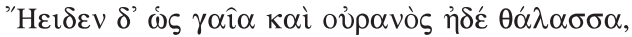

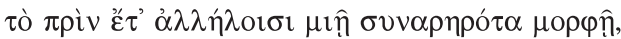

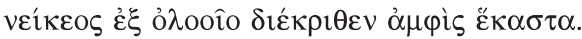

Then too Orpheus

lifted up his lyre with his left hand and tried out a song.

He sang of how the earth, sky, and sea, at one time combined together

in a single form, through deadly strife became separated each from the other (Apoll. Rhod. 1.

497-501; Fraenkel, 1970; Race, 2009).

Investigating development of the plot in The Argonautica, we can clearly observe that the song performed by Orpheus was not in any way determined by the action of the Rhodian's poem, conclusively, its subject appears to be a his typical repertoire, something what he usually presented to his audience. We can also see there that the beginning of the world was an object of interest for Linos and Orpheus, which can also be a proof that works of the poet discussed in this chapter could be a source of teachings for Orphics, since their subject matter resembled the poem of Orpheus.

The only thing missing in our analysis of Linos' theogony is an answer to the question about its title. It is possible that we know the title owing to the mention in Stobaeus' Florilegium. That author has written in his work that Linos had created

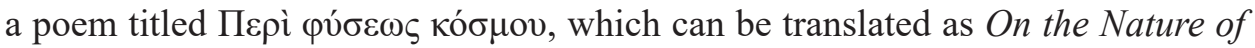
the World (Stob. Flor. 1.10.5). We find the discussion of this fragment alongside with its English translation in West's The Orphic poems. He suggests its connection with the fragment from Damascius' De principiis. It is probable that the poem included the idea of unity in multiplicity (Świercz, 2008), popular among Orphics (at least according to later scholars). Perhaps mentions of the genealogy of gods, found in those sources, were a part of that poem.

Certain scholars, e.g. West, argue that most works ascribed to Linos stemmed from different philosophical currents: from the Presocratics (including Anaxagoras) to the Stoics and the Pythagoreans (West, 1983: 58). The author of The Orphic Poems reached this conclusion on the basis of the quote of the Lives of Diogenes, saying:

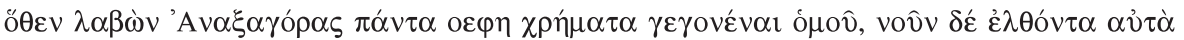
$\delta ı \kappa \kappa \sigma \mu \hat{\eta} \sigma \alpha \iota$.

and this idea was borrowed by Anaxagoras when he declared that all things were originally together until Mind came and set them in order (Diog. Laert. 1.4; Long, 1966; Hicks, 1972).

At the end there is a one more remark to be made. Pausanias wrote that the majority of works ascribed to Linos were forgeries, and if he did write something, it did not survive (Paus. 8.18.1). However, neither Pausanias nor West do not try 
to explain why so many texts were ascribed to Linos. Mythology answers this question. It presented their relation - both in terms of family and science. Linos was considered, among other things, a brother of Orpheus. Pseudo-Apollodorus wrote in the Bibliotheca:

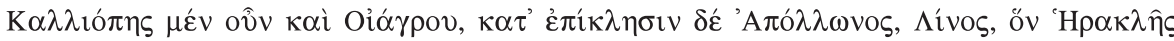

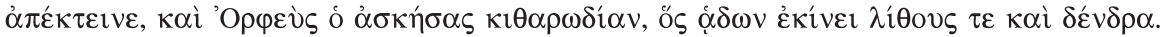

Now Calliope bore to Oeagrus or, nominally, to Apollo, a son Linos, whom Hercules slew; and another son, Orpheus, who practised minstrelsy and by his songs moved stones and trees (Apollod. 2.4.9; Wagner, 1894; Frazer, 1921).

The sources also mention Linos as Orpheus' great-grandfather (Suid. s.v. Homerus; Certamen 4). Some of them say that he was also his disciple (Nikom. 266.2) or a teacher (Diod. 3.67.2; Tz. Ex. Il. p. 17.9). That Orpheus was taught by Linos we can read in The Suda lexicon, where it was written:

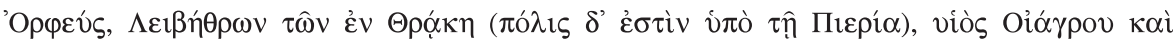

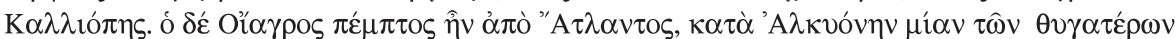

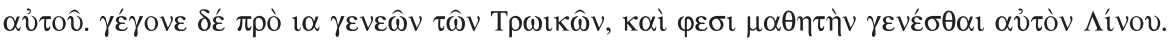

Orpheus, of Leibethra in Thrace (the town is below Pieria), son of Oiagros and Kalliope. Oiagros was in the fifth generation after Atlas, by Alkyone, one of his daughters. He lived 11 generations before the Trojan Wars, and they say he was a student of Linos (Suid. s.v. Orpheus; Adler, 1967-1971).

It was much easier for the Orphics to imagine that Linos the poet, as a brother of the mythical founder of the orphism or as his teacher, was the author of the Orphic poems. The only biographical mention about Linos at Pausanias could also be helpful for the understanding of its role as an Orphics' teacher. Pausanias was, since, convinced that Linos was a poet just like Orpheus and that he had written some poems. He described him in Periegesis in the following way:

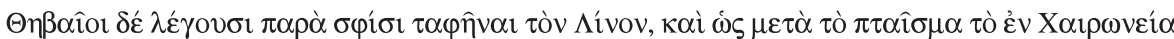

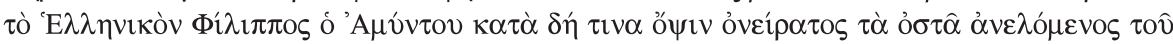

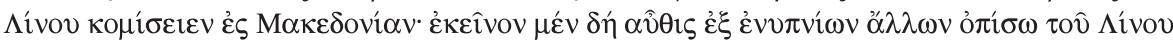

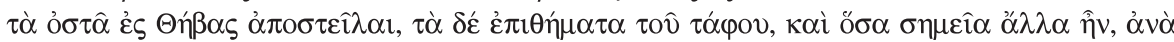

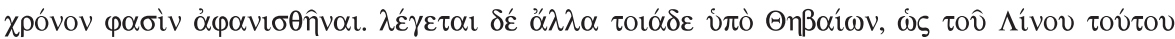

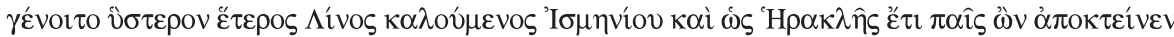

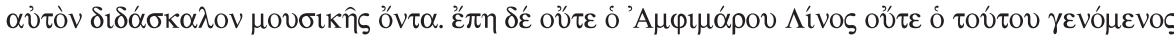

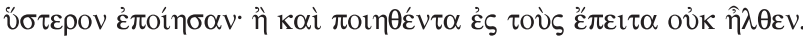

The Thebans assert that Linos was buried among them, and that after the Greek defeat at Chaeroneia, Philip the son of Amyntas, in obedience to a vision in a dream, took up the bones of Linos and conveyed them to Macedonia; other visions induced him to send the bones of Linos back to Thebes. But all that was over the grave, and whatever marks were on it, 
vanished, they say, with the lapse of time. Other tales are told by the Thebans, how that later than this Linos there was born another, called the son of Ismenius, a teacher of music, and how Heracles, while still a child, killed him. But hexameter poetry was written neither by Linos the son of Amphimarus nor by the later Linos; or if it was, it has not survived for posterity (Paus. 8.18.1; Rocha-Pereira, 1973-1981; Jones, 1966-1971).

As we can see, in Pausanias' work there are two mythological figures that went by the name of Linos and we cannot be actually sure to which one Pausanias ascribed the composition of theogony discussed above. It appears that, just in case, he ascribed those texts to both of them. It is thus irrelevant which Linos he means, we can see that in the above fragment, as well as in the earlier mention, he doubts the existence of his actual works. In spite of the fact that in that mention he contradicts himself, quoting the fragment from Linos' text.

Summarizing, it should be stated that Linos in Pausanias' work was supposed to present in his songs some elements of Orphic theogonies that were consistent in content with Hesiod's Theogony and a similar description of creation of deities parodied in the Birds of Aristophanes. It also resembles the theogony of Eudemus of Rhodes was concerned with. It is also possible that the theogony of Linos preferred Chaos as the first deity, from whom, among others, Oceanus and Tethys emerged. That pair of deities was soon to conceive Styx. It is also possible that the poem described also the beginning of the world in Orphic context and exhibit the idea, present among the Pythagoreans, of unity from which multiplicity stems and to which it returns. It was successfully proven that Linos was for the Orphics the creator of their hieroi logoi of almost equal meaning as Musaeus, despite scholars usually question this fact. It became possible in the imagination of the Greeks owing to his close, mythological connection to Orpheus and because he was perceived first of all as a poet.

\section{Bibliography}

Adler, A. (1967-1971). Suidae lexicon. 4 vols. Leipzig: Bibliotheca Teubneriana.

Ahbel-Rappe, S. (2010). Damascius Problems and Solutions Concering First Principles. Oxford: Oxford University Press.

Athanassakis, A. N., Wolkow B. M. (2013). The Orphic Hymns. Baltimore: Johns Hoskins University Press.

Bernabé, A. (1995). Una cosmogonía cómica. Aristófanes, Aves 685 ss. In: J. A. López (ed.). De Homero a Libanio. Estudios actuales sobre textos griegos II. Madrid: Ediciones Clásicas. 195-211.

Bernabé, A. (1998). Platone e l'orfismo. In: G. Sfameni Gasparro (ed.). Destino e salvezza. Tra culti pagani e gnosi cristiana. Itinerari storico-religiosi sulle orme di Ugo Bianchi. Cosenza: L. Giordano. 37-97.

Bernabé, A. (2007). Poetae Epici Graeci. Testimonia et Fragmenta. Pars II: Musaeus, Linus, Epimenies, Papytus Papyrus Derveni, Indices. Vol. 3. Berlin: De Gruyter.

Bernabé, A. (2011). Platón y el orfismo. Diálogos entre religión y filosofía. Madrid: Abada Editores. Betegh, G. (2004). The Derveni Papyrus. Cosmology, theology and interpretation. Cambridge: Cambridge University Press. 
Borgeaud, Ph., Pirenne-Delforge V. (2008). Opera inedita. Essai sur la religion grecque. Recherches sur les Hymnes orphiques. Liège: Centre International d'Étude de la religion Grecque Antique.

Burnet, J. (1967). Platonis opera. Vol. 1. Oxford: Clarendon Press.

Casadesùs, F. (2008). Orfeo y orfismo en Platón. In: A. Bernabé, F. Casadesús (eds.). Orfeo y la tradición órfica. Un reencuentro, Madrid: Akal. 1239-1280.

Christopoulos, M. (2010). Dark-Winged Nyx and Bright-Winged Eros in Aristophanes' "Orphic» Cosmogony. The Birds. In: M. Christopoulos et al. (eds.), Light and Darkness in Ancient Greek Myth and Religion. Lanham: Lexington Book. 207-220.

Dunbar, N. (1995). Aristophanes. Birds. Oxford: Oxford University Press.

Fayant, M. Ch. (2014). Hymnes Orphiques. Paris: Les Belles Lettres.

Fowler, H. N. (1970). Plato in Twelve Volumes. Cratylus, Parmenides, Greater Hippias, and Lesser Hippias. Vol. 4. Cambridge: Harvard University Press.

Fraenkel, H. (1970). Apollonii Rhodii Argonautica. Oxford: Clarendon Press.

Frazer, J. G. (1921). Apollodorus. The Library. Vol. 2. London: Heinemann.

Hicks, R. D. (1972). Diogenes Laertius. Lives of Eminent Philosophers. Cambridge: Harvard University Press.

Janko, R. (2002). „The Derveni Papyrus. An interim text”. Zeitschrift für Papyrologie und Epigraphik (141). 1-62.

Jiménez, A. I. (2004). „Tratti orfici nella ornitogonia degli Uccelli di Aristofane”. Chaos e kosmos (5). $1-15$

Jones, W. H. S. (1966-1971). Pausanias. Description of Greece. 5 vols. Cambridge: Harvard University Press.

Kouremenos, Th., Parássoglou, G. M., Tsantsanoglou, K. (2006). The Derveni Papyrus. Firenze: Olschki.

Laks, A., Most, G. W. (1997). Studies on the Derveni Papyrus. Oxford: Clarendon Press.

Long, H. S. (1966). Diogenis Laertii vitae philosophorum. 2 vols. Oxford: Clarendon Press.

Martínez, R. B. (2008). Lino. In: A. Bernabé, F. Casadesús (eds.). Orfeo y la tradición órfica. Un reencuentro, Madrid: Akal. 560-564.

Martínez, R. B. (2008). Otros poetas griegos proximos a Orfeo. In: A. Bernabé, F. Casadesús (eds.). Orfeo y la tradición órfica. Un reencuentro. Madrid: Akal. 549-579.

Morand, A. F. (2001). Études sur les Hymnes orphiques. Leiden: Brill.

Most, G. W. (2006). Hesiod. Theogony, Works and Days, Testimonia. Cambridge: Harvard University Press.

O’Neill, E. (1938). Aristophanes. Birds. The Complete Greek Drama. 2 vols. New York: Random House.

Race, W. H. (2009). Apollonius Rhodius. Argonautica. Cambridge: Harvard University Press.

Ricciardelli, G. (2000). Inni orfici. Milano: Mondadori.

Ricciardelli, G. (2008). Los Himnos órficos. In: A. Bernabé, F. Casadesús (eds.). Orfeo y la tradición órfica. Un reencuentro, Madrid: Akal. 325-348.

Rocha-Pereira, M. H. (1973-1981). Pausaniae Graeciae descriptio libri 1-10. 3 vols. Leipzig: Bibliotheca Teubneriana.

Ruelle, C. E. (1964). Damascii successoris dubitationes et solutiones. 2 vols. Brussels: Culture et Civilisation.

Świercz, P. (2008). Jedność wielości. Świat, czlowiek, państwo w refleksji nurtu orficko-pitagorejskiego. Katowice: Wydawnictwo Uniwersytetu Śląskiego.

Trzcionkowski, L. (2013). Bios-Thanatos-Bios. Semiofory orfickie z Olbii i kultura polis. Warszawa: Sub Lupa.

Von Albrecht, M. (1997). A History of Roman Literature. Leiden-New York-Koln: Brill.

Wagner, R. (1894). Apollodori bibliotheca. Pediasimi libellus de duodecim Herculis laboribus. Leipzig: Bibliotheca Teubneriana.

West, M. L. (1966). Hesiod. Theogony. Oxford: Clarendon Press.

West, M. L. (1983). Linus. In: Idem (ed.), The Orphic Poems, Oxford: The Clarendon Press. 53-67. 